\title{
Evaluation Abu-Dleek Sheep Leathers Properties
}

\author{
Nasr $\mathrm{AI}^{1 *}$, Azzam $\mathrm{AH}^{1}$ and Abdelsalam $\mathrm{MM}^{2}$ \\ ${ }^{1}$ Department of Wool Production and Technology, Desert Research Center, Egypt \\ ${ }^{2}$ Department of Animal Production, Alexandria University, Egypt
}

*Corresponding author: Ahmed Nasr, Department of Wool Production and Technology, Desert Research Center, Egypt, Tel: +201117281279; Email: ainasr@yahoo.com

\section{Research Article}

Volume 3 Issue 1

Received Date: January 16, 2020

Published Date: February 04, 2020

DOI: $10.23880 /$ izab- 16000201

\section{Abstract}

Abu-Dleek sheep are from animal hair producers and live under arid conditions and hot climate. This study aims to evaluate the physical and chemical properties of Abu-Dleek tanned leathers. Fifteen sheep skins were collected and divided into three tanning groups; chrome tanning, vegetable tanning with quebracho and vegetable tanning with mimosa. After tanning, all tanned leathers were tested physically and chemically. Data showed increments in tensile strengh, tearing strengh, bursing stretch, permeabiliy of water vapor, $\mathrm{pH}$ and ash values of chrome tanned leathers versus vegetable tanned leathers. The results declared the superurity of the chrome tanned leathers' quality, while quebrcho tanned leathers' quality was surpased mimosa tanned leathers. It could be concluded the convenient of Abu-Dleek tanned leathers to be used in a wide range of manufacuring purposes like garments, bags and lining.

Keywords: Leather Tanning; Physcial and Chemical Properties; Sheepskin

\section{Introduction}

In Egypt there are about 5.7 million heads of sheep [1]. Abu-Dleek sheep is from the most spread breeds in Upper Egypt especially El-Shalateen-Halaib triangle region [2,3]. Abu-Dleek animals are classified as hair producer sheep instead of wool [4]. The aforementioned region is a mountainous desert with several valleys dissecting mountains and located at the extreme south east of Egypt (22o 28' 09" N, 35o 31' 23"). Thus, these small ruminants and camels are the main available livestock in this area, depending on natural grazing [5].

Almost all skins coming from Sudan and south of Egypt are usually tanned in Cairo \& Alexandria tanneries [3]. Globally, mineral tanning with chromium salt is the most widely used in tanneries, while quebracho and mimosa extracts are the most used in vegetable tanning method [6].
Therefore, this investigation aimed to study the effect of tanning materials; chrome, quebracho and mimosa on AbuDleek leathers' quality.

\section{Materials and Methods}

The present study was carried out on 15 skins of AbuDleek sheep at marketing age (18 months). All animals were reared at El-Shalateen Research Station, which belongs to Desert Research Center, Egypt. After slaughtering, skins were preserved by salting and then transported to Kalash tannery at El-Max region, Alexandria, Egypt for tanning procedures. The skins were common in beam house process steps till tanning, thereafter pickled pelts were divided into three tanning groups $(\mathrm{n}=5)$; chrome, quebracho, and mimosa groups. In the chrome tanning group, pelts were tanned by adding $6 \%$ chromium sulphate (Basisty 33\%) from pelts weight and then neutralization step was performed by adding 
$1 \%$ sodium bicarbonate gradually, whilst in quebracho and mimosa tanning groups, pelts were tanned by adding $20 \%$ of vegetable extract in two equal batches.

All finished leathers were tested physically and chemically at the laboratories of Egyptian organization for standardization and quality control, Cairo, according to Egyptian Standards [7,8], respectively. Physical properties were thickness $(\mathrm{mm})$, tensile strength $\left(\mathrm{Kg} / \mathrm{cm}^{2}\right)$, tear strength $(\mathrm{Kg} / \mathrm{cm})$, elongation (\%), bursting stretch $(\mathrm{mm})$, permeability to water vapor $\left(\mathrm{mg} / \mathrm{mm}^{2} . \mathrm{hr}\right)$ and water absorption (\%), while chemical properties were moisture $(\%)$, fat (\%), ash (\%) and $\mathrm{pH}(\mathrm{ml} \mathrm{mol} / \mathrm{L})$.

Data were analyzed by one way compare means using computer program of SAS [9] to evaluate the effect of tanning materials on the finished Abu-Dleek leathers. The fixed effect of the used model was $Y_{i j}=\mu+T_{i}+e_{i j}$, where $Y_{i j}$ is the observation taken ( $j$ ), $\mu$ is the overall mean, $T_{i}$ is the fixed effect (i) of tanning materials and $e_{i j}$ is a random error assumed to be normally distributed with mean $=0$ and variance $=\sigma^{2} \mathrm{e}$.

\section{Results and Discussion}

Physical properties data for Abu-Dleek tanned leathers by different tanning materials are shown in Table 1 . Both chrome and vegetable tanned leathers were in acceptable ranges for leather manufacturing purposes, such as garments, bags and lining [10]. When comparing Abu-Dleek sheepskin as a hair animal producer with Barki sheepskin that produces wool under the harsh conditions, it is noticed that Abu-Dleek tanned leathers in this investigation surpassed those obtained previously from Barki tanned leathers [11]. The increment was found in tensile strength, tearing strength, elongation, permeability to water vapor, and water absorption. In this regard, Jackson-Mass and Snyman [12] found the same trend between hair-sheep breeds and woolsheep breeds in South Africa. From our point of view, it could be suggested that these results may be due to the changes in hair fiber diameters and thence the histological differences of skin dermis layer.

On the other hand, data showed that (Table 1), the effect of tanning materials were significantly $(\mathrm{P}<0.05)$ differentially influenced the leather thickness, tearing strength and bursting stretch properties, whereas, other physical properties were mathematically different but insignificant. This clearly indicated that chrome tanned leathers were with the highest quality being the thinnest $(0.78 \mathrm{~mm})$ and the highest in tensile strength $\left(213.20 \mathrm{Kg} / \mathrm{cm}^{2}\right)$, tearing strength $(51.80 \mathrm{Kg} / \mathrm{cm})$ and with the most permeability to water vapor ( $439 \mathrm{mg} / \mathrm{mm}^{2} . \mathrm{hr}$ ). This trend was expected because the inverse relationship between skin thickness and strengths values of tanned leathers [2,13]. In the meantime, chromium salts make more crosslinks with collagen fibers and in turn its lability is lower than in vegetable tanned leathers, which makes chrome tanned leathers more compressed [14,15].

\begin{tabular}{|c|c|c|c|c|c|c|c|c|}
\hline \multirow{2}{*}{$\begin{array}{l}\text { Tanning } \\
\text { Material }\end{array}$} & \multirow{2}{*}{$\begin{array}{l}\text { Thickness } \\
\text { (mm) }\end{array}$} & \multirow{2}{*}{$\begin{array}{c}\text { Tensile } \\
\text { strength } \\
(\mathrm{Kg} / \mathrm{cm} 2)\end{array}$} & \multirow{2}{*}{$\begin{array}{c}\text { Tearing } \\
\text { strength } \\
(\mathrm{Kg} / \mathrm{cm})\end{array}$} & \multirow{2}{*}{$\begin{array}{l}\text { Elongation } \\
\text { (\%) }\end{array}$} & \multirow{2}{*}{$\begin{array}{c}\text { Bursting } \\
\text { stretch } \\
\text { (mm) }\end{array}$} & \multirow{2}{*}{$\begin{array}{c}\text { PWV (mg/mm2/ } \\
\text { hr) }\end{array}$} & \multicolumn{2}{|c|}{$\begin{array}{c}\text { Water Absorp- } \\
\text { tion (\%) }\end{array}$} \\
\hline & & & & & & & $2 \mathrm{hrs}$ & 24hrs \\
\hline Chrome & $0.780^{\mathrm{b}}$ & 213.2 & $51.80^{\mathrm{a}}$ & 55.8 & $9.54^{\mathrm{ab}}$ & 439 & 193.2 & 237.6 \\
\hline Quebracho & $1.176^{\mathrm{a}}$ & 196.76 & $48.26^{a}$ & 61.26 & $10.42^{\mathrm{a}}$ & 428 & 188.25 & 223.5 \\
\hline Mimosa & $1.360^{\mathrm{a}}$ & 170 & $36.76^{\mathrm{b}}$ & 64.4 & $8.74^{\mathrm{b}}$ & 406 & 190 & 196.2 \\
\hline SEM & 0.076 & 10.7 & 2.37 & 2.66 & 0.27 & 19.2 & 5.21 & 8.43 \\
\hline Significance & $*$ & NS & $*$ & NS & $*$ & NS & NS & NS \\
\hline
\end{tabular}

a,b Means in the same column having different superscripts are significantly different $(\mathrm{P}<0.05)$.

PWV: Permeability to water vapor,

SEM: standard error of mean,

NS: Not Significance, ${ }^{*} \mathrm{P}<0.05$

Table 1: Means \pm SEM of physical properties as affected by tanning materials of Abu-Dleek tanned leathers.

Additionally, the thickness increase in vegetable tanned leathers is attributable to the effect of acid fermentation in tan liquors by yeast, as a result of the sugar content in vegetable tanning extracts. Therefore, mimosa tanned leathers were the thicker and lower quality than quebracho tanned leathers, which ascribed to the excess amount of sugar in mimosa extract [6].
There are significant increases $(\mathrm{P}<0.01)$ in both of ash and $\mathrm{pH}$ values in chrome tanned leathers, whereas, vegetable tanned leathers (quebracho and mimosa) were comparable (Figure 1). This increase in ash value is a result of chromium salts addition, whilst the highest $\mathrm{pH}$ value is referred to the neutralization step in chrome tanning only. Therefore, the obtained results are in agreement with acceptable ranges for 
chrome and vegetable tanned leathers [10].

\section{Conclusion}

An added value could be acquired from the Abu-
Dleek breed in Egypt as a sheep-hair producer breed, which increases their tanned leather quality. In turn, it is convenient to use Abu-Dleek tanned leathers in a wide range of manufacuring purposes like garments, bags and lining.

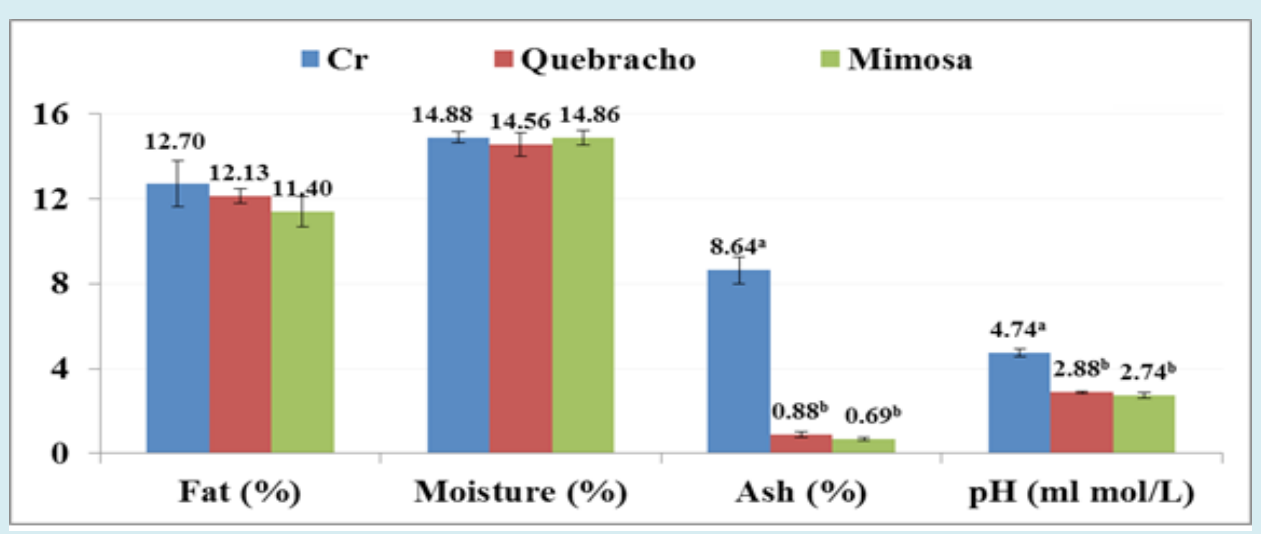

Figure 1: Chemical properties as affected by tanning materials of Abu-Dleek tanned leathers.

\section{References}

1. FAOSTAT (2019) Production-Crops data. World Food And Agriculture Organization, Rome.

2. Abdelsalam MM, Haider AI (1993) Physical and histological properties of sheep and goat skins. Alexandria J Agric Res 38: 117-124.

3. Azzam AH (2003) Application of some untraditional methods for skin preservation in some desert areas. J Agric Sci 28(7): 5215-5223.

4. Guirgis R, El-Ganaieny M (1998) Some observations on the coat of small ruminants in the extreme south of Egypt. Egyptian J Animal Prod 35: 417-428.

5. El Nahrawy M (2011) Country Pasture/Forage Resource Profiles, Egypt.

6. Dutta SS (2008) An Introduction to the principles of leather manufacture. $4^{\text {th }}$ (Edn.), Indian Leather Techno Association, India.

7. ES 122 (2013) Methods of sampling and physical testing of leather. Egyptian Standards Organization, Egypt.
8. SAS (2008) SAS/STAT 9.2 User's Guide. 2nd (Edn.), SAS Institute Inc., Cary, NC, USA, pp: 28-74.

9. BASF (2007) Pocket book for leather technologist. 4th (Edn.), Badische Anilin-und Soda-Fabrik, 67056 Ludwigshafen, Germany, pp: 454.

10. Nasr AI, Abdelsalam MM, Azzam AH (2013) Effect of tanning method and region on physical and chemical properties of Barki sheep leather. Egyptian Journal of Sheep and Goat Sciences 8(1): 123-130.

11. Jackson Mass C, Snyman M (2000) A comparison of the leather produced from the skins of ten different South Africa sheep breeds. South African J Animal Sci 30(S1): 129-130.

12. Taha EA, Samia AH, Nasr AI (2017) Evaluating skin quality of some rabbit breeds under Egyptian conditions. World Rabbit Science 25: 193-200.

13. Anthony D (1998) New tannages for the new millennium. J American Leather Chemists Asso 93: 168-182.

14. Covington AD (2011) Tanning chemistry the science of leather. RSC Publishing, Cambrige, London. 